Extended abstract of presentation at

NATO Advance Workshop "Regional aspects of climate-terrestrial-hydrologic interactions in Eastern

Europe” (NEESPI Regional Non-boreal Europe Meeting) Odessa, Ukraine, August 23-28, 2008

\title{
The NASA NEESPI Data Portal to Support Studies of Climate and Environmental Changes in Non-boreal Europe
}

\author{
Suhung Shen ${ }^{1}$, Gregory Leptoukh ${ }^{2}$, Tatiana Loboda ${ }^{3}$, Ivan Csiszar ${ }^{3}$, Peter Romanov ${ }^{3}$, \\ Irina Gerasimov ${ }^{4}$
}

1 George Mason University / NASA GSFC, Greenbelt, MD, 20771

2 NASA GSFC, Greenbelt, MD, 20771

3 University of Maryland, College Park, MD 20742

4 ADNET / NASA GSFC, Greenbelt, MD, 20771

Keywords: remote sensing, online visualization, analysis, fire, NDVI

\section{Introduction:}

NASA NEESPI (Northern Eurasia Earth Science Partnership Initiative) data portal is a NASA funded project that focuses on collecting satellite remote sensing data, providing tools, information, and services in support of NEESPI scientific objectives (Leptoukh, et al., 2007). The data can be accessed online through anonymous ftp, through an advanced data searching and ordering system - Mirador that uses keywords to find data quickly in a Google-like interface, and through the Goddard Interactive Online Visualization ANd aNalysis Infrastructure (Giovanni). The portal provides preprocessed data from different satellite sensors and numerical models to the same spatial and temporal resolution and the same projection so that the data can be used easily to perform inter-comparison or relationship studies. In addition, it provides parameter and spatially subsetted data for regional studies.

Studies of regional carbon, hydrology, aerosols in non-boreal Europe and their interactions with global climate are very challenging research topics. The NASA NEESPI data portal makes many satellite data available for such studies, including information on land cover types, fire, vegetation index, aerosols, land surface temperature, soil moisture, precipitation, snow/ice, and other parameters. This paper will introduce the features and products available in the system, focusing on the online data 
tool, Giovanni NEESPI. An example that explores different data through Giovanni NEESPI in temperate region of non-boreal Europe will be presented.

\section{Features of Giovanni NEESPI}

Giovanni is developed by the NASA Goddard Earth Sciences Data and Information Services Center (GES DISC). It provides a simple and intuitive way to visualize, analyze, and access vast amounts of Earth science data without having to download the data (Acker and Leptoukh, 2007; Berrick, et al 2008). The system consists of the following components: the easy use Web interfaces, back-end data processing software, image renders, and an instance generator. The instance generator can create customized Giovanni instances based on scientific needs by selecting desired analysis functions and parameters of one or more satellite instruments or numerical models from Giovanni database. Giovanni has been used widely to explore data and conduct initial studies, for example, dust and aerosol (Ramachandran \& Cherian 2008); ocean color (Shen et al., 2008); and precipitation (Huffman, et al., 2007).

Giovanni NEESPI is a customized Giovanni that integrates atmospheric, land surface and cryospheric products from a number of sensors within the boundaries of Northern Eurasia in support of the NEESPI project. This instance allows for visualization of parameters through plot functions including latitude-longitude area maps, animations, time-series, and cross-sections (Latitude/Longitude-Time and HeightLatitude/Longitude). It enables comparisons or relationship studies between parameters through functions, such as scatter plots, correlation coefficient maps, difference, and overlays. Other features of Giovanni NEESPI include: downloading original full spatial coverage or intermediate subsetted data for a region of interest in different formats, such as ASCII, hdf, or netCDF; provide products lineage which presents brief descriptions of how images and data were created; and provides images with KMZ format that can be viewed through Google Earth. In addition, Giovanni NEESPI can be accessed in a machine-to-machine way via WMS and WCS protocols. It can act as Web Mapping Service (WMS) or Web Coverage Service (WCS), thus allowing any GIS clients to add layers or get subsetted data from Giovanni. Finally, the system can act as a client by getting remotely located data via WCS or WMS. 


\section{Products in Giovanni NEESPI:}

Two Giovanni NEESPI instances are in operation. The first instance includes monthly products from MODIS Terra, MODIS Aqua, AMSR-E, AIRS and NESDIS/IMS. The parameters in the monthly instance have been grouped into three groups: atmosphere, land surface and cryosphere. Another operational instance is for daily products. It contains mostly atmospheric parameters from MODIS Terra, MODIS Aqua, and a few land surface parameters from AIRS. Both operational instances contain products of $1^{\mathrm{o}} \mathrm{x} 1^{\mathrm{o}}$ horizontal resolution. We are working on higher resolution daily or 8day products to better support regional-scale studies. Table 1 lists parameters, instrument name, temporal coverage and status of products in Giovanni-NEESPI.

Table 1: Parameters in Giovanni-NEESPI system:

\begin{tabular}{|c|c|c|c|c|c|}
\hline \multirow[t]{2}{*}{ Group } & \multirow[t]{2}{*}{ Parameter Name } & \multirow{2}{*}{$\begin{array}{l}\text { Sensor } \\
\text { Name }\end{array}$} & \multirow{2}{*}{$\begin{array}{l}\text { Available } \\
\text { since }\end{array}$} & \multicolumn{2}{|c|}{ Status } \\
\hline & & & & monthly & daily \\
\hline \multirow{15}{*}{ Atmosphere } & Aerosol Optical Depth at 0.55 micron & $\begin{array}{l}\text { MODIS-Terra } \\
\text { MODIS-Aqua }\end{array}$ & $\begin{array}{l}2000.02 \\
2002.07\end{array}$ & OPS & OPS \\
\hline & $\begin{array}{l}\text { Atmospheric Water Vapor (QA- } \\
\text { weighted) }\end{array}$ & $\begin{array}{l}\text { MODIS-Terra. } \\
\text { MODIS-Aqua }\end{array}$ & $\begin{array}{l}2000.02 \\
2002.07 \\
\end{array}$ & OPS & OPS \\
\hline & Aerosol Small Mode Fraction & $\begin{array}{l}\text { MODIS-Terra, } \\
\text { MODIS-Aqua }\end{array}$ & $\begin{array}{l}2000.02 \\
2002.07 \\
\end{array}$ & OPS & OPS \\
\hline & Cloud Fraction (Day and Night) & $\begin{array}{l}\text { MODIS-Terra, } \\
\text { MODIS-Aqua }\end{array}$ & $\begin{array}{l}2000.02 \\
2002.07 \\
\end{array}$ & OPS & OPS \\
\hline & Cloud Fraction (Day only) & $\begin{array}{l}\text { MODIS-Terra, } \\
\text { MODIS-Aqua }\end{array}$ & $\begin{array}{l}2000.02 \\
2002.07\end{array}$ & OPS & OPS \\
\hline & Cloud Fraction (Night only) & $\begin{array}{l}\text { MODIS-Terra, } \\
\text { MODIS-Aqua }\end{array}$ & $\begin{array}{l}2000.02 \\
2002.07\end{array}$ & OPS & OPS \\
\hline & Cloud Optical Depth - Total (QA-w) & $\begin{array}{l}\text { MODIS-Terra, } \\
\text { MODIS-Aqua }\end{array}$ & $\begin{array}{l}2000.02 \\
2002.07\end{array}$ & OPS & OPS \\
\hline & Cloud Optical Depth - Ice (QA-w) & $\begin{array}{l}\text { MODIS-Terra, } \\
\text { MODIS-Aqua }\end{array}$ & $\begin{array}{l}2000.02 \\
2002.07\end{array}$ & OPS & OPS \\
\hline & Cloud Optical Depth - Liquid (QA-w) & $\begin{array}{l}\text { MODIS-Terra, } \\
\text { MODIS-Aqua }\end{array}$ & $\begin{array}{l}2000.02 \\
2002.07 \\
\end{array}$ & OPS & OPS \\
\hline & $\begin{array}{l}\text { Cloud effective radius - Total (QA- } \\
\text { W) }\end{array}$ & $\begin{array}{l}\text { MODIS-Terra, } \\
\text { MODIS-Aqua }\end{array}$ & $\begin{array}{l}2000.02 \\
2002.07\end{array}$ & OPS & OPS \\
\hline & $\begin{array}{l}\text { Cloud effective radius - Ice (QA- } \\
\text { W) }\end{array}$ & $\begin{array}{l}\text { MODIS-Terra, } \\
\text { MODIS-Aqua }\end{array}$ & $\begin{array}{l}2000.02 \\
2002.07\end{array}$ & OPS & OPS \\
\hline & $\begin{array}{l}\text { Cloud effective radius - Liquid } \\
\text { (QA-W) }\end{array}$ & $\begin{array}{l}\text { MODIS-Terra, } \\
\text { MODIS-Aqua }\end{array}$ & $\begin{array}{l}2000.02 \\
2002.07\end{array}$ & OPS & OPS \\
\hline & Cloud Top Pressure (Day and Night) & $\begin{array}{l}\text { MODIS-Terra, } \\
\text { MODIS-Aqua }\end{array}$ & $\begin{array}{l}2000.02 \\
2002.07\end{array}$ & OPS & OPS \\
\hline & Cloud Top Pressure (Day only) & $\begin{array}{l}\text { MODIS-Terra, } \\
\text { MODIS-Aqua }\end{array}$ & $\begin{array}{l}2000.02 \\
2002.07\end{array}$ & OPS & OPS \\
\hline & Cloud Top Pressure (Night only) & $\begin{array}{l}\text { MODIS-Terra, } \\
\text { MODIS-Aqua }\end{array}$ & $\begin{array}{l}2000.02 \\
2002.07\end{array}$ & OPS & OPS \\
\hline
\end{tabular}




\begin{tabular}{|c|c|c|c|c|c|}
\hline & $\begin{array}{l}\text { Cloud Top temperature (Day and } \\
\text { Night) }\end{array}$ & $\begin{array}{l}\text { MODIS-Terra, } \\
\text { MODIS-Aqua }\end{array}$ & $\begin{array}{l}2000.02 \\
2002.07\end{array}$ & OPS & OPS \\
\hline & Cloud Top temperature (Day only) & $\begin{array}{l}\text { MODIS-Terra, } \\
\text { MODIS-Aqua }\end{array}$ & $\begin{array}{l}2000.02 \\
2002.07\end{array}$ & OPS & OPS \\
\hline & Cloud Top temperature (Night only) & $\begin{array}{l}\text { MODIS-Terra, } \\
\text { MODIS-Aqua }\end{array}$ & $\begin{array}{l}2000.02 \\
2002.07 \\
\end{array}$ & OPS & OPS \\
\hline & Column Amount Ozone & Aura OMI & 2004.08 & NA & OPS \\
\hline & GPCP precipitation & GPCP Derived & 1979.01 & OPS & WK \\
\hline \multirow{11}{*}{$\begin{array}{l}\text { Land } \\
\text { Surface }\end{array}$} & $\begin{array}{l}\text { Cloud and Overpass Corrected Fire } \\
\text { Pixel Count }\end{array}$ & $\begin{array}{l}\text { MODIS-Terra } \\
\text { MODIS-Aqua }\end{array}$ & $\begin{array}{l}2000.11 \\
2002.07\end{array}$ & OPS & WK \\
\hline & Overpass Corrected Fire Pixel Count & $\begin{array}{l}\text { MODIS-Terra } \\
\text { MODIS-Aqua }\end{array}$ & $\begin{array}{l}2000.11 \\
2002.07 \\
\end{array}$ & OPS & WK \\
\hline & $\begin{array}{l}\text { Mean Cloud Fraction over Land for } \\
\text { Fire Detection }\end{array}$ & $\begin{array}{l}\text { MODIS-Terra } \\
\text { MODIS-Aqua }\end{array}$ & $\begin{array}{l}2000.11 \\
2002.07 \\
\end{array}$ & OPS & WK \\
\hline & Mean Fire Radiative Power & $\begin{array}{l}\text { MODIS-Terra } \\
\text { MODIS-Aqua }\end{array}$ & $\begin{array}{l}2000.11 \\
2002.07\end{array}$ & OPS & WK \\
\hline & Enhanced Vegetation Index (EVI) & $\begin{array}{l}\text { MODIS-Terra } \\
\text { MODIS-Aqua }\end{array}$ & $\begin{array}{l}2000.02 \\
2002.07 \\
\end{array}$ & OPS & WK \\
\hline & $\begin{array}{l}\text { Normalized Difference Vegetation } \\
\text { Index (NDVI) }\end{array}$ & $\begin{array}{l}\text { MODIS-Terra } \\
\text { MODIS-Aqua }\end{array}$ & $\begin{array}{l}2000.02 \\
2002.07\end{array}$ & OPS & WK \\
\hline & Land Surface Temperature (daytime) & MODIS-Terra & 2000.03 & OPS & WK \\
\hline & Land Surface Temperature (nighttime) & MODIS-Terra & 2000.03 & OPS & WK \\
\hline & Surface Air Temperature & AIRS & 2002.08 & OPS & OPS \\
\hline & Surface Skin Temperature & AIRS & 2002.08 & OPS & OPS \\
\hline & Land Cover Type & MODIS Terra & 2001.01 & TS & NA \\
\hline \multirow{2}{*}{ Cryosphere } & Ice Occurrence Frequency & NESDIS/IMS & 2000.01 & OPS & WK \\
\hline & Snow Occurrence Frequency & NESDIS/IMS & 2000.01 & OPS & WK \\
\hline
\end{tabular}

Note: $\mathrm{OPS}=$ operational, $\mathrm{TS}=$ in test, $\mathrm{WK}=$ working on, $\mathrm{NA}=$ no data

\section{Sample Application: Variations of Fire in Temperate Europe}

As an example application of Giovanni NEESPI, we have studied interannual variations of fire occurrence in the temperate regions of non-boreal Europe. At 1 degree resolution, land cover of temperate Europe is dominated by three major classes: croplands, mixed forest, and grasslands. The official statistics on wildland fire occurrence in Europe (excluding Russian Federation, Armenia, and Georgia) show that over the last decade on the average $75 \%$ of all burned areas in Europe were found in Spain, Portugal, Italy, and Greece positioned in southern subtropical Europe (UNECE Timber Committee and the FAO European Forestry Commission: http://www.unece.org/trade/timber/ff-stats.html). Satellite observations show that in temperate Europe fires or hot spots occur mainly in croplands (Fig. 1). Using Giovanni NEESPI, we have studied the variations of fire frequency observed in this region from 
satellites. Figure 2 shows monthly time series of fire pixel counts from MODIS Terra and MODIS Aqua over the cropland regions. Fire occurrence has clear seasonal variations in this region. It features two fire peaks: one in spring (March and April) and another in late summer (July and August). The spring peak is generally weaker than the one in late summer. Previous studies (Korontzi et al., 2006) have indicated that agricultural fires are common in this region. These fires are frequently set as a crop residue management application which allows for inexpensive and quick stubble removal while adding nutrients to the soil and killing weeds and pests at the same time. Despite the official ban on agricultural burning in many countries of Western Europe (Jenkins et al., 1992) a considerable number of fires are observed in cropland areas there. Agricultural use of fire is even more prominent in Eastern Europe where cropland fires presented $\sim 86 \%$ of all detected fire activity in Ukraine during 2001-2003 (Korontzi et al, 2006).

F ire occurrence in late summer of year 2003 was noticeably lower as compared to other years during 2001-2007. Considering that fires in this region are associated with crop growth, we investigated the precipitation and vegetation index in this region through Giovanni NEESPI. The precipitation was derived from the NASA GPCP monthly product. The vegetation index was derived from MODIS Terra and MODIS Aqua normalized difference vegetation index (NDVI). We found that the late summer fire in temperate cropland region has a strong relationship with spring precipitation and NDVI in early summer (Fig. 3a). The amount of precipitation in spring 2003 was noticeably smaller compared to other years which may have caused the stunted crop growth in this region. The latter is indicated by the lower NDVI values in May through July. The weaker growing season resulted in a reduced production of winter wheat in Ukraine from $\sim 3 \mathrm{mt} /$ ha in 2001 and 2002 to $1.5 \mathrm{mt} / \mathrm{ha}$ in 2003 with a subsequent increase in yields up to $\sim 3 \mathrm{mt} / \mathrm{ha}$ in 2004 (USDA/FAS/PDS, 2008). However, a similar drop in spring precipitation and subsequent lower NDVI values observed in 2007, has not led to decrease in the fire activity during that year. Our analysis of additional parameters available in Giovanni NEESPI shows that it might have been linked to unusually high land surface temperature observed during July-September of 2007 (Fig. 3b). 


\section{Summary:}

This paper presents a quick summary of the NASA NEESPI data portal and the Giovanni NEESPI system. The study of variability of fire occurrence in temperate Europe demonstrates that Giovanni NEESPI is a convenient, simple, and useful tool for exploring satellite remote sensed data aimed at developing an understanding of continental- and regional-scale relationships between various parameters and processes.

More products including modeled and long term in situ data and more visualization functions will be added into the data portal to better support climate studies. We are working on a prototype to allow the portal to access data dynamically from other center through WMS and WCS, such as regional high resolution data. This will make the portal a virtual universal data center that allows scientists to access data from a single point.

\section{Acknowledgement:}

The project is supported by NASA through ROSES 2005 NNH05ZDA001NACCESS. The authors wish to express great appreciation for the technical support of the Giovanni software development and S4PA data ingest working groups at NASA GESDISC.

\section{Relevant URL:}

The NASA NEESPI Data Center: http://neespi.gsfc.nasa.gov/

Giovanni: http://giovanni.gsfc.nasa.gov

\section{References:}

Acker, J. and G. Leptoukh, 2007. Online Analysis Enhances Use of NASA Earth Science Data, EOS, Transactions of American Geophysical Union, 88, 14. 
Berrick, Stephen W., Gregory Leptoukh, John Farley, Hualan Rui, 2008. Giovanni: A Web Services Workflow-Based Data Visualization and Analysis System, IEEE Trans. on Geos. \& RS, accepted.

Huffman, G. J., Adler, R. F., Bolvin, D. T., Gu, G., Nelkin, E. J., Bowman, K. P., Hong, Y., Stocker, E. F., \& Wolff, D. B. (2007). The TRMM multisatellite precipitation analysis (TMPA): quasi-global, multiyear, combined-sensor precipitation estimates at fine scales. J. Hydrometeorology, 8, 38-55, doi:10.1175/JHM560.1.

Jenkins, B.M., Turn, S.Q., and R.B. Williams. 1992. Atmospheric emissions from agricultural burning in California: determination of burn fractions, distribution factors, and crop-specific contributions. Agriculture, ecosystems \& environment. 38(4) 313-330.

Leptoukh, G., Csiszar, I., Romanov, P., Shen S., Loboda T., \& Gerasimov, I. 2007. NASA NEESPI data center for satellite remote sensing data and services. Global and Planetary Change, Environ, Res. Lett., 2. 045009, doi:10.1088/1748-9326/2/4/045009.

Korontzi, S., McCarty, J., Loboda, T., Kumar, S., Justice, C., 2006. Global distribution of agricultural fires in croplands from 3 years of Moderate Resolution Imaging Spectroradiometer (MODIS) data. Global Biogeochemical Cycles, 20, GB2021, doi:10.1029/2005GB002529.

Ramachandran, S. \& Cherian, R. (2008). Regional and seasonal variations in aerosol optical characteristics and their frequency distributions over India during 2001-2005. J. Geophysical Res., 113, D08207, doi:10.1029/2007JD008560.

Shen, S., Leptoukh, G. G., Acker J. G., Yu, Z., \& Kempler, S. J. (2008). Seasonal variations of chlorophyll a concentration in the Northern South China Sea. IEEE Geoscience and Remote Sensing Lett., 5, 315-319. 
United States Department of Agriculture (USDA)/Foreign Agricultural Service (FAS)/Production Supply and Distribution (PSD), 2008. USDA official statistics on Production, Supply and Distribution of Agricultural Commodities Online.

http://www.fas.usda.gov/psdonline/psdHome.aspx Accessed 08/19/2008. 


\section{Figures:}

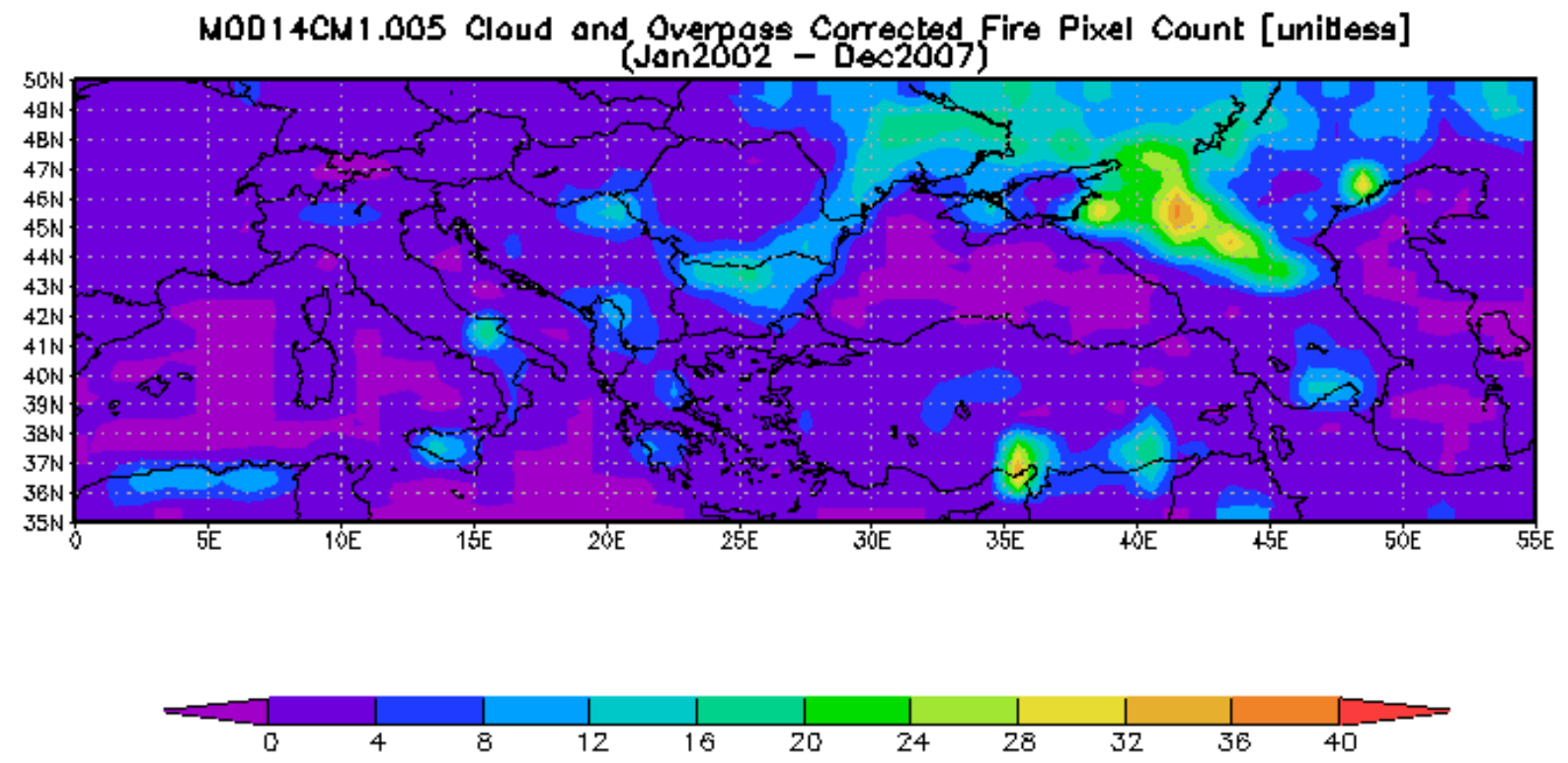

Figure 1: Fire pixel count observed from MODIS Terra over temperate Europe. The data were averaged from January 2002 to December 2007. 


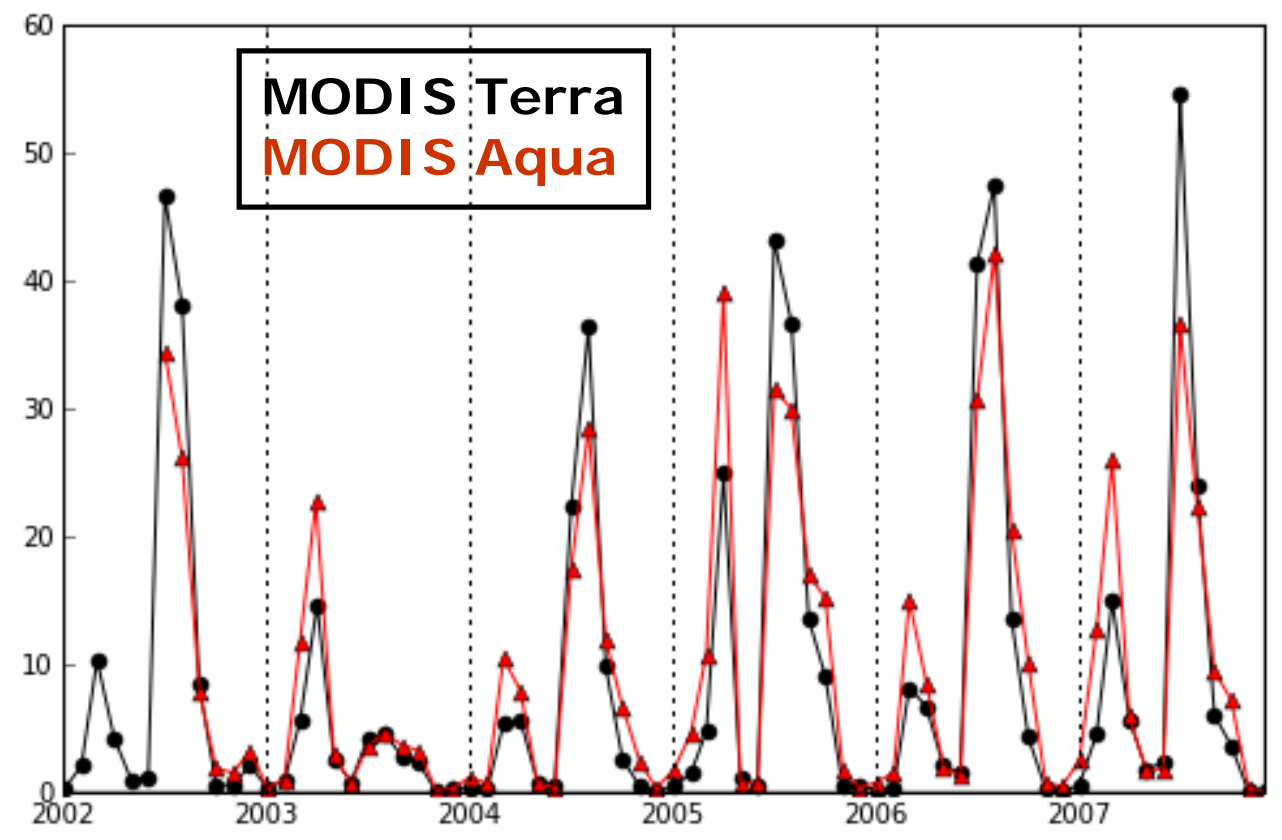

Figure 2: Monthly time series of cloud and overpass corrected fire pixel count over cropland regions of temperate Europe $\left(25^{\circ} \mathrm{E}-45^{\circ} \mathrm{E}, 42^{\circ} \mathrm{E}-50^{\circ} \mathrm{E}\right)$. The black curve is from MODIS Terra and the red curve is from MODIS Aqua. 

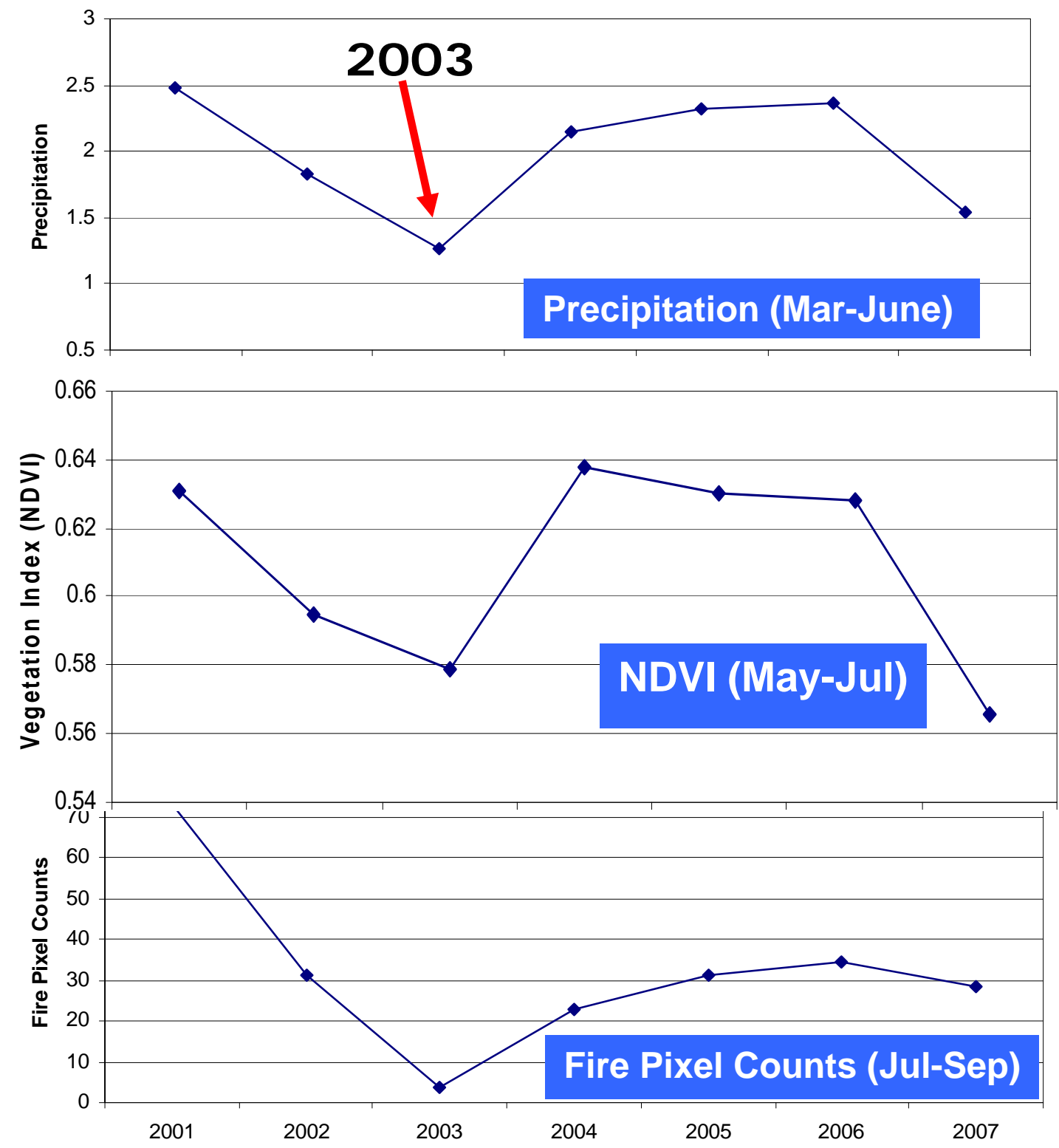

Figure 3a: Interannual variations of fires in July-September and its relationship with NDVI in May-July and precipitation in March-June. 

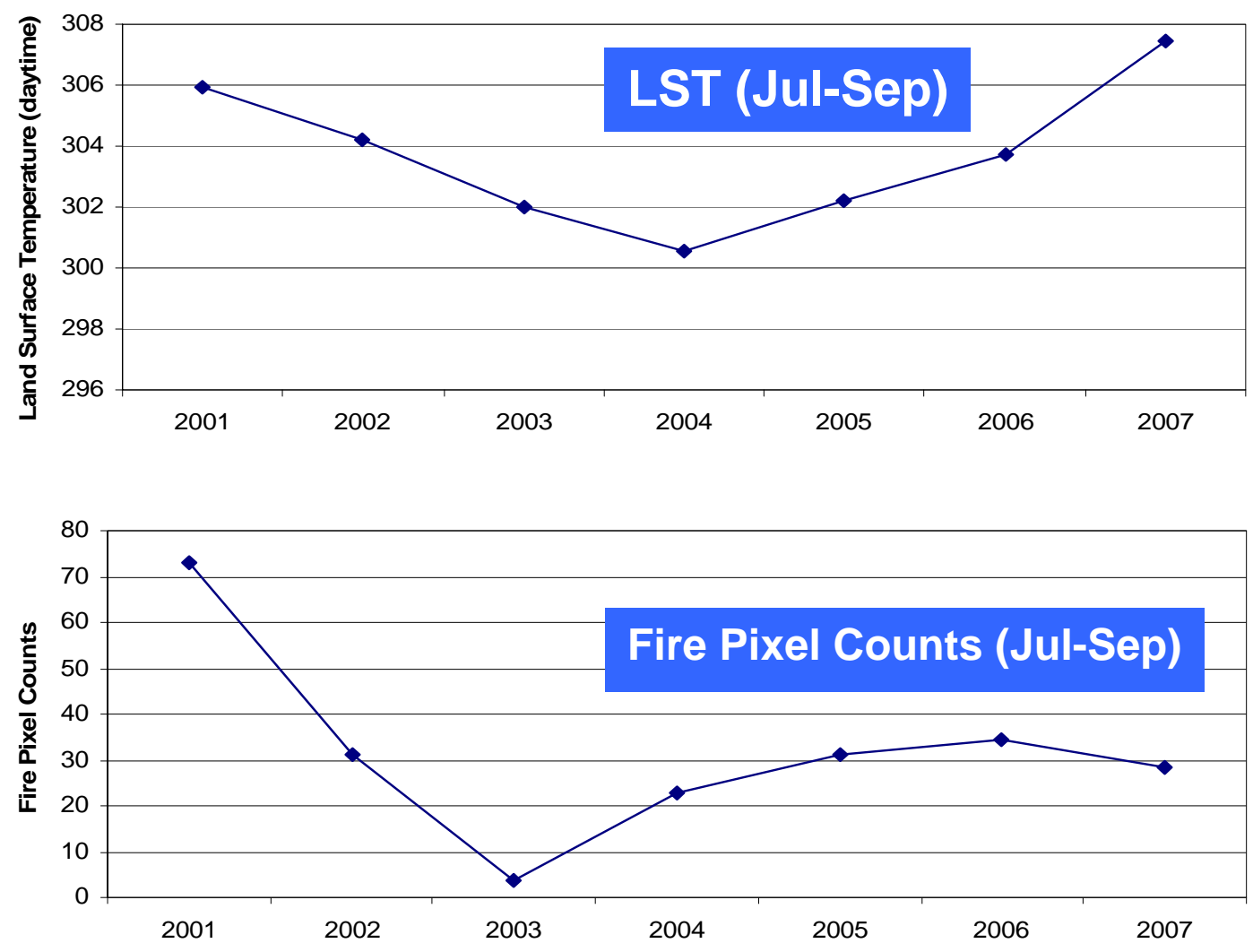

Figure 3b: Interannual variations of fires in July-September and its relationship with land surface temperature in same time period. 